\title{
Spatial heterogeneity in macroinvertebrate density from Lake Hövsgöl, Mongolia
}

\author{
Barbara Hayford ${ }^{1, *}$, Clyde Goulden ${ }^{2}$ and Bazartseren Boldgiv ${ }^{3}$ \\ ${ }^{1}$ Department of Life Sciences, Wayne State College, 1111 Main Street, Wayne, NE 68787, USA \\ ${ }^{2}$ Asia Center, Academy of Natural Sciences of Drexel University, 1900 Benjamin Franklin Parkway, Philadelphia, \\ PA, 19103, USA \\ ${ }^{3}$ Department of Ecology, National University of Mongolia, Ulaanbaatar 210646, Mongolia \\ *Correspondent: bahayfo1@wsc.edu.
}

\begin{abstract}
Typical of large, oligotrophic lakes, Lake Hövsgöl, Mongolia, exhibits complex morphometry which should support a spatially heterogeneous community of benthic macroinvertrates. The lake also exhibits a broad range of land uses. Based on the variation in land use and complex physical habitat of the lake (e.g. substrate variation and presence of affluent streams in bays), we asked two questions. First, does density of total benthic macroinvertebrates vary between different bays in Lake Hövsgöl? Second, does density of individual benthic taxa vary by bay? Samples collected in 1997, the last year for benthic sampling of the lake, were designed to test for variation in macroinvertebrate density between bays and can now be used to establish baseline variation in density for future studies. A total of 56 Ponar grab samples were analyzed from six bays in Lake Hövsgöl. Results of a general linear model analysis of variance showed that total density of macroinvertebrates varied only slightly between bays of the lake, but that most individual taxa showed significant variation between bays. Variation in density for most taxa was linked to substrate composition rather than other geographic or physical variables in the lake. Recent increases in grazing intensity and ecotourism along the shores should be managed to reduce the nutrient load into the lake to avoid impairment of the benthic biota of this unique, ancient ecosystem.
\end{abstract}

Keywords: conservation, environmental stressors, Lake Hövsgöl, macroinvertebrates, Mongolia

(C) 2013 National Institute of Biological Resources

DOI: 10.12651/JSR.2013.2.2.159

\section{INTRODUCTION}

Lake Hövsgöl is a large, ancient, asymmetrical graben lake located in north central Mongolia. The lake is long along its north/south axis and the west shore of the lake is lined by steep mountains with little human activity; whereas the east shore of the lake is lined by shallow hills characterized by pastoral land use. Lake Hövsgöl is a pristine lake with high concentrations of dissolved oxygen, low concentrations of nutrients, and deep blue color (Kozhova et al., 1994), earning it the moniker, the Blue Pearl of Mongolia. The lake is oligotrophic to extremely oligotrophic (Kalbe \& Schacke, 1996) and lake productivity is limited by nitrogen and phosphorus (Mitamura et al., 2010). However, environmental stressors such as overgrazing and increases in pollution resulting from tourism are on the rise. These stressors pose a serious threat to the unique ecosystems of Lake Hövsgöl, which as one of the world's largest lakes supports high levels of bio- logical diversity (Vadeboncoeur et al., 2011).

Spatially heterogeneous macroinvertebrate communities have been correlated to the complex physical and habitat environments of large, oligotrophic lakes (Rieradevall et al., 1999; Stoffels et al., 2005). Lake Hövsgöl is characterized by a large watershed comprised of over 90 affluent streams of which 20 sustain continuous flow for at least two months of the year (Goulden et al., 2006). Numerous bays have formed along the shoreline where the streams flow into the lake. These bays are composed of different substrates, depth gradients, and nutrients (Kozhova et al., 1989; Kozhova et al., 1994; Hayakawa et al., 2003; Hayford \& Ferrington, 2006; Urabe et al., 2006). Biodiversity and bathymetric distribution of macroinvertebrates in Lake Hövsgöl has been well documented (Kozhova et al., 1994; Erbaeva et al., 2006). However, none of the studies systematically examined patterns in density between bays, particularly in the southern half of the lake. The southern reaches of the lake's watershed are currently experiencing the greatest increase in tourism and great- 
est increase in livestock grazing due to its proximity to settlements (Pers. obs.). The last year in which benthic samples were collected throughout the lake was 1997. The sampling was designed to test for variation in density of macroinvertebrates between bays in the lake and now may provide a baseline analysis from which to monitor current and future changes in density of benthic macroinvertebrates.

The lake and its watershed have undergone significant change since 1997. Grazing along the eastern shore of Lake Hövsgöl has increased on average 7\% between 2003 and 2005 , with a maximum increase of $14 \%$ between 2003 and 2005. Increased grazing is a possible factor in variation in dissolved organic carbon and dissolved organic nitrogen between six affluent streams along the east shore of the lake (Puntsag et al., 2010). Grazing may also act indirectly by increasing the active layer depth, which in turn increases nutrient leaching with precipitation. Another potential anthropogenic stressor is human waste from increased population and tourism in the region. Tourism in Mongolia tripled between 1997 and 2004 (Yu \& Goulden, 2006) and may lead to localized increases in waste water run-off (e.g. Mbaiwa, 2003). Three to five thousand foreign tourists and 10-15 thousand domestic tourists are estimated to visit Lake Hövsgöl National Park each year, and most of them come to the southern end of the lake. If infrastructure development of tourist camps does not keep pace with growth of the tourist camps in the region, the result may be increased flow of untreated waste water into the lake (e.g. Mbaiwa, 2003). Once more nutrients and waste waters enter the lake it will take a long time for them to cycle out because the lake has an estimated residence time of between 300 and 600 years according to Hayami et al. (2006).

Due to the heterogeneity in habitats, macroinvertebrate density and community composition likely will vary by bay in Lake Hövsgöl. Density and community data collected in 1997 can serve as baseline, historical conditions by which to compare future samples from the lake. Therefore, we ask two questions. First, does density of total benthic macroinvertebrates vary between different bays in Lake Hövsgöl? Second, does density of individual benthic taxa vary by bay? Since future studies may document an increase in eutrophication along the east shore of the lake in response to grazing and tourism relative to the west shore, we further relate possible differences in density between bays along the east and west shores and between bays receiving affluent streams and those which do not.

\section{Materials ANd Methods}

\section{Study area}

Lake Hövsgöl's watershed is located at $49^{\circ} 53^{\prime}-52^{\circ}$ $00^{\prime} \mathrm{N}, 99^{\circ} 00^{\prime}-101^{\circ} 56^{\prime} \mathrm{E}$ in north central Mongolia. Maximum length of the lake is $136 \mathrm{~km}$, maximum width is $36.5 \mathrm{~km}$, and maximum depth is $262 \mathrm{~m}$. Lake area is $2760 \mathrm{~km}^{2}$ and volume of the lake is $381 \mathrm{~km}^{3}$. The area of the graben within which the lake is situated is $4920 \mathrm{~km}^{2}$. The lake is at an elevation of $1645 \mathrm{~m}$ above sea level (a.s.1.) and the highest elevation in its graben and hence watershed is $3491 \mathrm{~m}$ a.s.l. Lake Hövsgöl is surrounded by the Eastern Sayan Mountains to the north and the Horidol Saridag Mountains to the west (Goulden et al., 2006). The landscape to the east of the lake is characterized by low hills. The lake graben is asymmetrical with a steep western slope descending to the greatest depth and a shallow eastern slope. The Egiin gol is the only effluent stream and it drains the lake from the southern shore (Kozhova et al., 1989). It is a dimictic lake, overturning twice a year, once in May-June and once in October-November in the near shore regions and once in July and once in November in the deeper regions of the lake. The epilimnion is approximately $10 \mathrm{~m}$ thick during summer stratification, the thermocline is approximately $60 \mathrm{~m}$ thick (Hayami et al., 2006). Lake Hövsgöl along with its watershed area was designated as national park in 1992. Before that, the eastern shore was used as a drive-through area in which live animals were sent to sell to Russia.

\section{Macroinvertebrate sampling}

The six bays sampled from 9-10 July of 1997 were Har Us and an unnamed bay along the west shore (UBWS), Borsog, Baavgai Tolgoi, Heegster, and an unnamed bay along the east shore of the lake (UBES) (Fig. 1). At the time of sampling, the southwest shore was heavily impacted by tourism development and southeastern part was affected by grazing. However, Har Us and UBWS had not been affected much, except for seasonal tourism. Dalbay and Baavgai Tolgoi bays were not grazed during the 1990s, while Heegtser and UBES were most likely to be under grazing pressure (pers. obs.).

Har Us Bay is fed by one of the strongest flowing streams along the shore of the lake. It is believed by local people that Har Us stream possesses mineral water quality, so land use is non-existent, except for seasonal tourists. Har Us flows for a very short distance and since the stream flow rate and its mineral content are high, nutrient load may be high in this bay. The UBWSis also not affected by land use. Borsog Bay is fed by Borsog River which has a length of $11 \mathrm{~km}$ and a watershed area of about $67 \mathrm{~km}^{2}$, and maximum flow rate of $285 \mathrm{~m}^{3} \mathrm{~s}^{-1}$. The river flows into a large pond, which is sometimes disconnected by gravel bar from the lake water. The gravel may act as a barrier to sediment transport. Despite the presence of the wetland sedimentation rate in Borsog Bay has been 


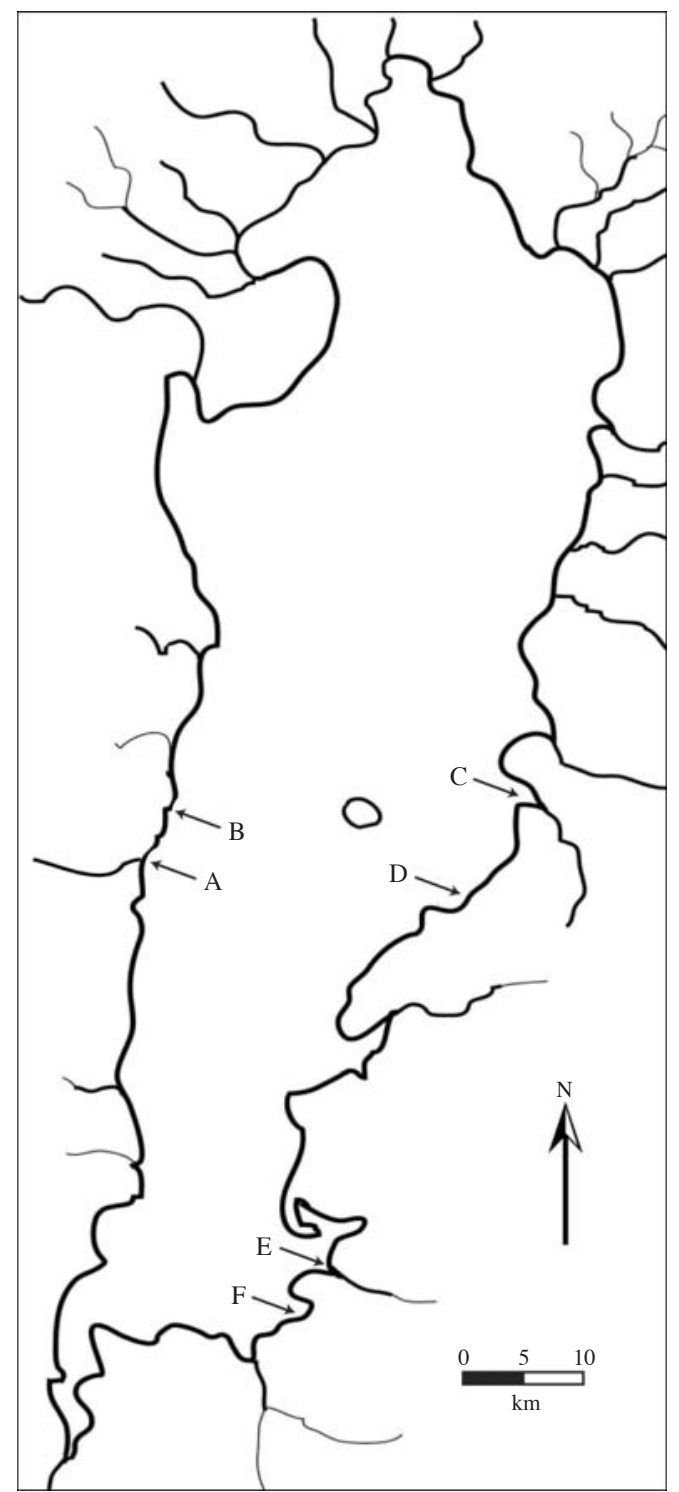

Fig. 1. Map of Lake Hövsgöl, Mongolia. Letters denote bay sites listed in Table 1. A (Har Us). B (UBWS). C (Borsog). D (Baavgai Tolgoi). E(Heegster). F(UBES). recorded at $0.08 \mathrm{~cm} / \mathrm{yr}$, which is a higher rate of sedimentation than the lake's pelagic bays (Orkhonselenge \& Kashiwaya, 2010). At the time of research, both Borsog and Baavgai Tolgoi were not under any land use impacts. Borsog currently is a part of special zone within the Lake Hövsgöl National Park.

Four of these bays received streams and two did not (Fig. 1, Table 1). Ten sites were selected randomly in each bay and were collected with a Ponar grab $\left(900 \mathrm{~cm}^{2}\right)$. Depths, presence or absence of affluent streams, lake side, and substrate were recorded for each site. Substrate was categorized as rocks ( $>256 \mathrm{~mm}$ in diameter), cobble and stones (64-256 $\mathrm{mm}$ in diameter), pebbles (=gravel) (2-64 $\mathrm{mm}$ in diameter), sand $(0.06-2 \mathrm{~mm}$ in diameter), silt (0.004-0.06 $\mathrm{mm}$ in diameter), clay $(<0.004 \mathrm{~mm}$ in diameter) and mud or sludge with fine organic particles as modified from Barbour et al. (1999). Macroinvertebrates were observed colonizing marl and Chara, which were also listed as substrate (Table 1). Dominance of substrate types per repeat samples was not recorded in the field, however, a simple type of dominant substrate per bay was calculated as the number of repeats in which a substrate was observed. For example, silt was found in more sites than other substrates in Borsog, thus it was considered the dominant substrate in that bay based on our sampling. If two or more substrates were found in the same number of repeat samples, they were both considered the dominant substrate (Table 1).

Sample depths ranged from 7 to $26 \mathrm{~m}$ with mean and median depth of $14 \mathrm{~m}$. Specimens were sorted on site by passing samples through a set of sieves with decreasing pore-size (top sieve mesh diameter $=2 \mathrm{~mm}$, middle mesh diameter $=500 \mu \mathrm{m}$, bottom sieve $=250 \mu \mathrm{m})$. Specimens were preserved in the field using $40 \%$ ethanol and subsequently preserved in the lab with $\sim 95 \%$ ethanol. Macroinvertebrates were sorted into major taxonomic groups and counted to determine density for each site. Samples from six sites were damaged and were removed from analysis resulting in a total of 54 samples.

Table 1. Depth, substrate, location, and presence or absence of affluent stream for bays sampled in this study.

\begin{tabular}{lcccccc}
\hline Bay (\# of replicates) & Har Us (10) & UBWS $(10)$ & Borsog $(8)$ & Baavgai Tolgoi (8) & Heegster (10) & UBES (8) \\
\hline Site code (Fig. 1) & A & B & C & D & E & F \\
Latitude & $50^{\circ} 54^{\prime} 59^{\prime \prime}$ & $50^{\circ} 59^{\prime} 05^{\prime \prime}$ & $50^{\circ} 59^{\prime} 29^{\prime \prime}$ & $50^{\circ} 53^{\prime} 51^{\prime \prime}$ & $50^{\circ} 35^{\prime} 46^{\prime \prime}$ & $50^{\circ} 33^{\prime} 45^{\prime \prime}$ \\
Longitude & $100^{\circ} 15^{\prime} 25^{\prime \prime}$ & $100^{\circ} 16^{\prime} 48^{\prime \prime}$ & $100^{\circ} 42^{\prime} 29^{\prime \prime}$ & $100^{\circ} 36^{\prime} 13^{\prime \prime}$ & $100^{\circ} 28^{\prime} 59^{\prime \prime}$ & $100^{\circ} 27^{\prime} 01^{\prime \prime}$ \\
Mean depth (m) & 15.45 & 15.85 & 11.94 & 11.31 & 15.90 & 16.50 \\
Affluent stream & P & A & P & A & P & P \\
Lake Side & West & West & East & East & East & East \\
Substrate $1 * *$ & Pebbles, silt & Sand, Marl & Silt & Pebbles, sand & Clay & Pebbles \\
Substrate 2 & Sand & Pebbles & Sand & Silt & Sand \\
Substrate 3 & Marl, Chara & Chara & Marl & & Silt \\
Substrate 4 & Clay & & Chara, mud & & Mud \\
\hline
\end{tabular}

*calculated as median of the different types of substrate present at bay sites.

**see methods for how substrate dominance was calculated. 


\section{Analysis}

Patterns of bays and macroinvertebrate taxa were analyzed using hierarchical cluster analysis and visualized on a double dendrogram. Clusters were linked using unweighted pair group averaging based on Euclidean distances and goodness of fit was based on the cophenetic correlation coefficient with a value of over 0.75 considered a good fit between the original data and resulting dendrogram.

Samples were collected along a relatively narrow range of depths, mostly from the littoral zone of the lake as defined by Hayford and Ferrington (2006). General linear model analysis of variance (GLM ANOVA) was used throughout the study because there were unequal numbers of sample repeats per bay. A one-way GLM ANOVA was used to test for significant variation in depth between bays. No significant variation between bays was detected so depth was not used as a variable in examining spatial heterogeneity in density of benthic macroinvertebrates from Lake Hövsgöl. Abundance data were converted to density data and transformed by natural log for statistical analyses. Density data for Hirudinea and Planaria did not meet assumptions of a normal distribution despite transformation and so were not included in statistical analyses except when included in analysis of total density. The

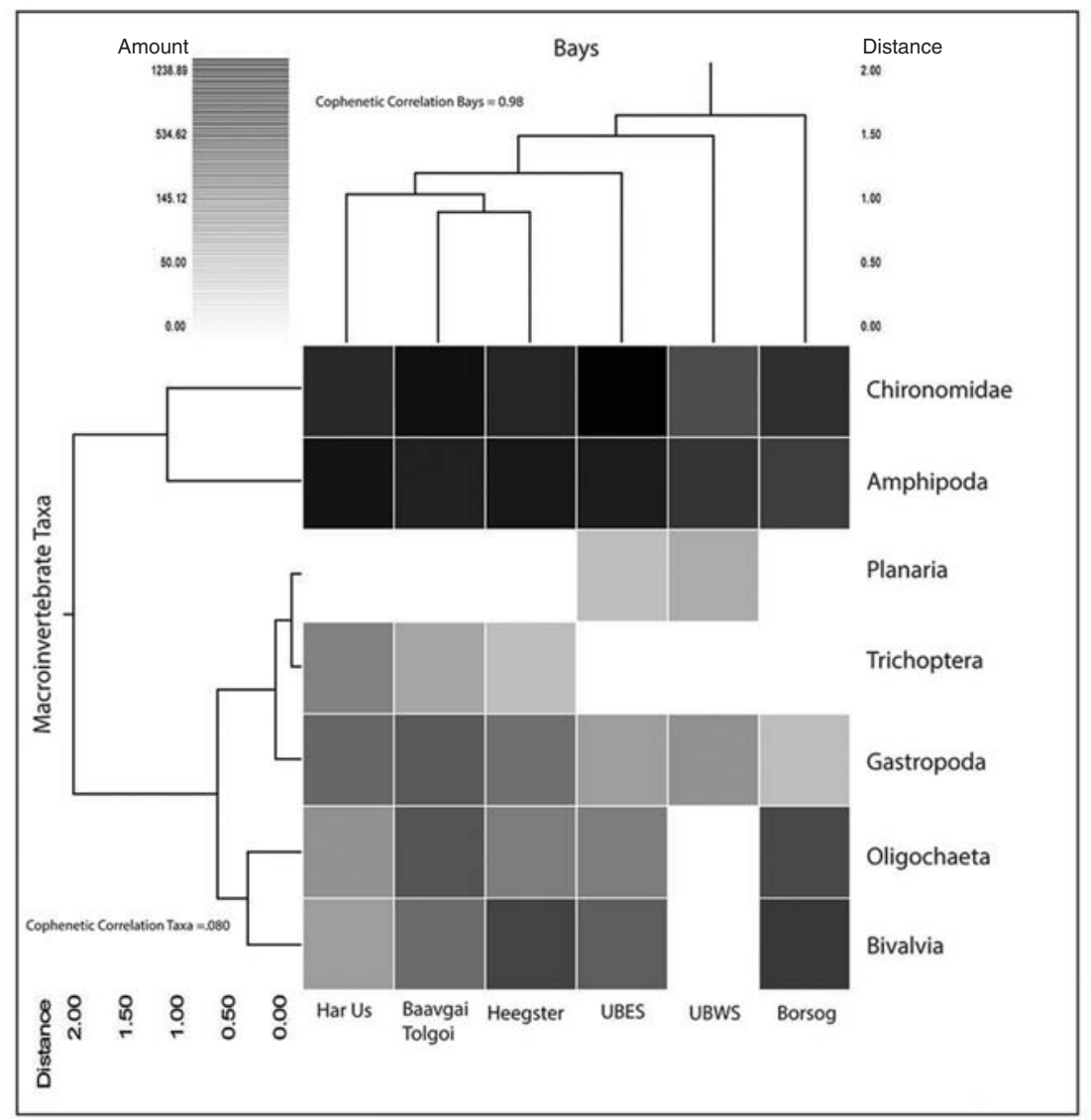

Fig. 2. Double dendrogram of major macorinvertebrate taxa and study bays in Lake Hövsgöl based on hierarchical cluster analysis.

Table 2. Density of macroinvertebrates from bays in Lake Hövsgöl expressed as minimum to maximum values followed by the (mean).

\begin{tabular}{lcccccc}
\hline \multicolumn{1}{c}{ Bay } & Har Us & UBWS & Borsog & Baavgai Tolgoi & Heegster & UBES \\
\hline Planaria & $0-11(4.44)$ & $0-44(15.56)$ & $0-33(6.94)$ & $0-22(6.94)$ & $0-33(5.56)$ & $0-22(8.33)$ \\
Oligochaeta & $0-89(46.67)$ & $0-11(3.33)$ & $11-356(205.56)$ & $0-333(125)$ & $0-256(87.78)$ & $0-167(70.83)$ \\
Bivalves & $0-144(41.11)$ & $0-22(3.33)$ & $0-689(369.44)$ & $11-178(88.89)$ & $156-1600(440.00)$ & $0-278(127.78)$ \\
Gastropoda & $11-356(138.89)$ & $0-144(55.56)$ & $0-56(13.89)$ & $56-189(116.67)$ & $0-233(91.11)$ & $0-78(33.33)$ \\
Amphipoda & $200-1144(753.33)$ & $267-911(507.78)$ & $122-1222(473.61)$ & $244-1000(615.28)$ & $344-1244(745.56)$ & $267-1289(708.33)$ \\
Trichoptera & $0-88.89(50.00)$ & $0-22.22(4.44)$ & $0-11(2.78)$ & $0-56(23.61)$ & $0-56(12.22)$ & $0-11(4.17)$ \\
Chironomidae & $211-1211(576.67)$ & $0-433(157.78)$ & $44-1056(520.83)$ & $122-1177(852.78)$ & $188-1511(690.00)$ & $644-1755(1181.94)$ \\
Total Density & $744-2644(1611.11)$ & $300-1222(747.78)$ & $456-2378(1593.06)$ & $467-2389(1844.44)$ & $1222-3000(2072.22)$ & $1278-3100(2134.72)$ \\
\hline
\end{tabular}


GLM ANOVAs were used to test whether density of macroinvertebrates varied significantly between bays. Significance was set at $P \leq 0.05$. All statistical analyses were performed using Number Crunching Statistical Software ${ }^{\circledR}$. Use and spelling of site names followed Boldgiv's recommendations in Goulden et al. (2006). Bays were named for their affluent stream, if present.

\section{Results}

A total of 7998 macroinvertebrates from eight major taxa were sampled in this study. Total macroinvertebrate density was greatest in UBES, a bay along the southeast shore of the lake. Amphipoda and Chironomidae comprised the greatest proportion of overall macroinvertebrate density with over 1700 chironomids and nearly 1300 amphipods collected from UBES (Fig. 1, Table 2). Hirudinea and Ostracoda were only collected in one repeat sample each and were not represented in Table 2. Planaria were collected in low densities. Trichoptera and Gastropoda had highest densities in Har Us along the west shore of the lake (Fig. 1, Tables 1 and 2). Bivalves and oligochaetes had greatest densities in Borsog and Heegster, two bays with silt and clay substrates common (Tables 1 and 2).

Low total macroinvertebrate density and low diversity separated UBWS from the other bays in the study (Fig. 2, Table 2). Borsog also separated out from the other bays based on fewer taxa present combined with high densities of bivalves and oligochaetes (Fig. 2, Table 2). Heegster, Baavgai Tolgoi, and Har Us grouped with UBES based on presence of the six out of the seven taxa in the study and Har Us, Baavgai Tolgoi and Heegster grouped together based on the presence of Trichoptera, with UBES separating out based on the presence of Planaria (Fig. 2, Table 2). Spatial patterns in density for the bays in the dendrogram did not correspond to location (e.g. east versus west side of the lake) or presence or absence of affluent streams (Fig. 2, Table 1). Chironomidae and Amphipoda grouped together due to their presence and high densities at all sites; whereas, Trichoptera and Planaria grouped together based on their patchy distribution amongst the sites (Fig. 2). Gastropoda formed an outgroup with Trichoptera and Planaria, but the cause of this grouping was unclear (Fig. 2). Oligochaeta and bivalves grouped together based on co-occurrence in five of the six study bays and by exhibiting the greatest densities in Borsog Bay (Fig. 2).

Total macroinvertebrate density varied significantly between UBWS and the other bays (Fig. 3). Amphipod density did not significantly vary between bays (Fig. 4). Oligochaete, bivalve, and chironomid density were significantly lower in UBWS relative to the other bays (Fig. 4). Gastropod density was significantly lower in Borsog

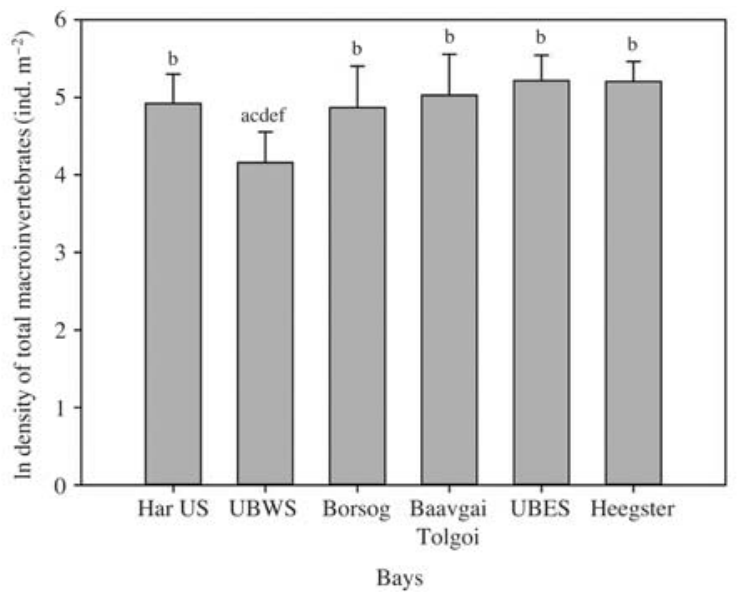

Fig. 3. Mean $( \pm 1 \mathrm{SE})$ density of total macroinvertebrates from bays in Lake Hövsgöl. Bars with different letters are significantly different $(P \leq 0.05)$.

Bay relative to gastropod densities in Har Us, Baavgai Tolgoi, and Heegster Bays. Trichoptera density was significantly greater in Har Us Bay relative to the other bays and was significantly greater in Baavgai Tolgoi Bay relative to densities in UBWS and Borsog Bays (Fig. 4).

\section{Discussion}

The results indicate that total macroinvertebrate density and community composition varied spatially in Lake Hövsgöl, at least between the most unique site, UBWS, and the other sites (Figs. 2, 3). Total density and diversity were lowest in UBWS, a bay without an affluent stream (Fig. 1, Table 1), even compared to Baavgai Tolgoi, the other bay lacking an affluent stream (Table 1, Fig. 1). The UBWS had the most lacustrine environment of all study sites and was the furthest removed from nutrient input from the watershed. Lake Hövsgöl was shown to exhibit spatial variation in nutrient concentrations related to the location of affluent streams (Hayakawa et al., 2003; Urabe et al., 2006), so it is possible that UBWS had lower nutrient concentrations and so supported the lowest densities of macroinvertebrates in this ultra-oligotrophic lake.

Individual taxa clearly exhibited a greater degree of spatial variation than did the total macroinvertebrate community, with the exception of Amphipoda and Chironomidae (Figs. 3, 4). Amphipoda were homogeneous between all bays and Chironomidae were homogeneous between all bays except for UBWS where they had significantly lower density (Figs. 2, 4). Chironomidae and Amphipoda were the numerically dominant macroinvertebrates in the bays sampled (Fig. 2, Table 2), corroborating previous studies on Lake Hövsgöl (Kozhova et al., 

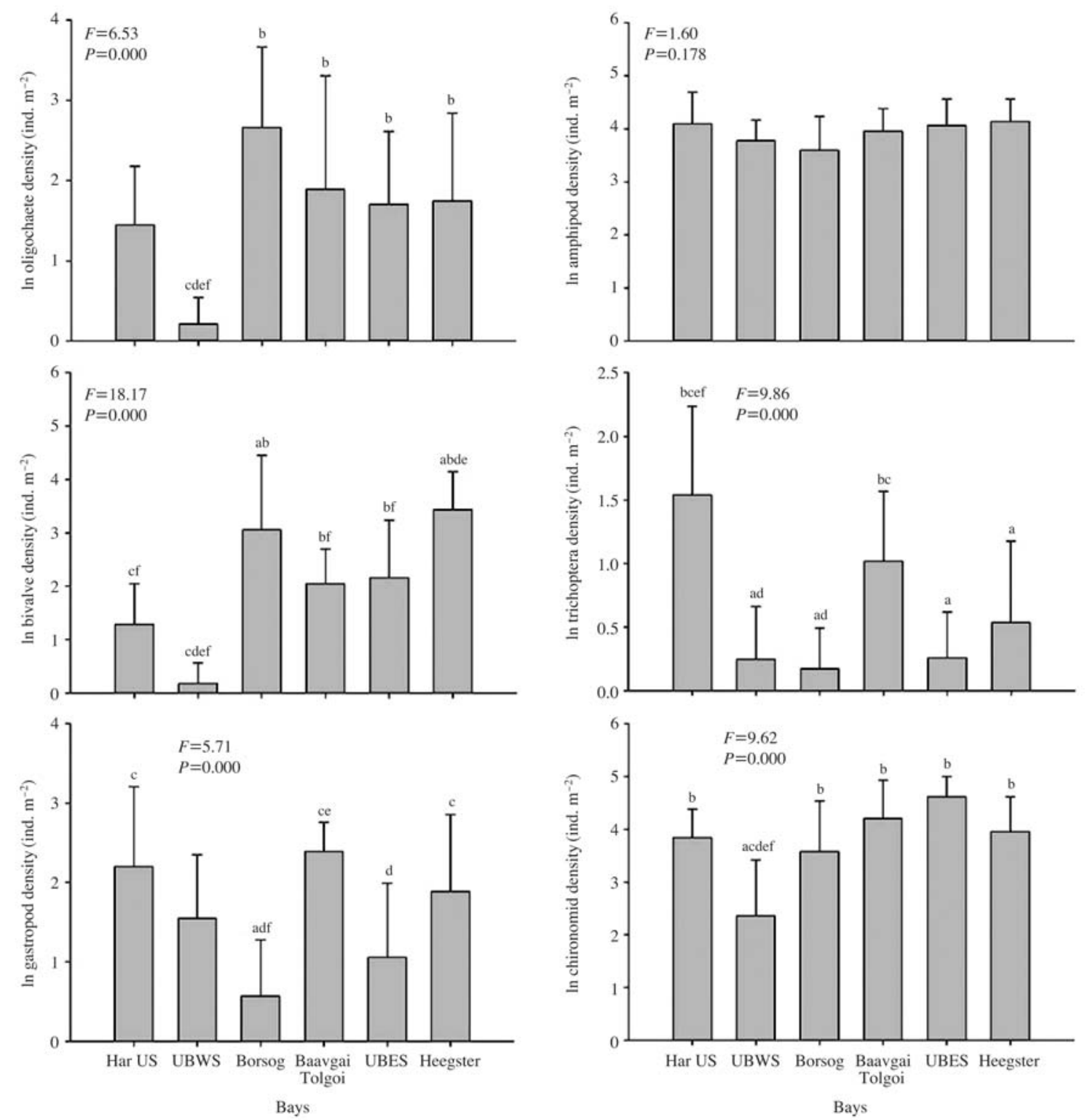

Fig. 4. Mean $( \pm 1 \mathrm{SE})$ density of individual macroinvertebrate taxa from bays in Lake Hövsgöl. Bars with different letters are significantly different $(P \leq 0.05)$.

1994; Erbaeva et al., 2006). The amphipods of Lake Hövsgöl comprised about $12 \%$ of the abundance for the entire lake (Safronov, 2006) and they were ubiquitous throughout the lake (Kozhova et al., 1994; Erbaeva et $a l .$, 2006). Their ubiquitous nature may account for their relative spatial homogeneity in this study. Previous studies on Lake Hövsgöl have shown greater spatial heterogeneity in Chironomidae than was indicated by this study. However, those studies were not restricted to bays and incorporated data on depths greater than the depths incorporated in this study (Kozhova et al., 1989; Erbaeva et al., 2006; Hayford \& Ferrington, 2006).

The remaining taxa exhibited much more spatial varia- tion than did amphipods and chironomids (Fig. 4). Oligochaetes and bivalves most likely varied based on substrate composition (Fig. 4, Table 1). Oligochaetes and lacustrine bivalves are often dominant taxa in soft substrates (Rieradevall et al., 1999; Cummings \& Graf, 2010; Govedich et al., 2010). Our data showed that they were dominant taxa in two east shore bays characterized by clay and silt (Fig. 4, Table 1). Both Borsog and Heegster Bays are fed by watersheds comprised of narrow, spring-fed streams flowing over fine sediments and rocks (Pers. obs.) and the process of runoff from these watersheds contributes to the soft substrates in the bays over time. In fact, Orkhonselenge and Kishiwaya (2010) found that the thick 
sediment in Borsog Bay was formed during pulses of high sedimentation rates related to periods of high runoff and from melting alpine glaciers at 940 and 4580 years before present. Sedimentation resulting from these long-term historical processes may be exacerbated by activities such as over-grazing (e.g. Belsky et al., 1999) in the region possibly resulting in increased and more rapid sedimentation in these bays.

Trichoptera and gastropods also varied between bays with different substrate composition. Both taxa had greater densities in Har Us and Baavgai Tolgoi, bays characterized by a mix of pebbles, silt, and sand (Fig. 4, Table 1). Rieradevall et al. (1999) showed that Trichoptera and gastropods were absent from soft sediments in an alpine lake in the Pyrenees and showed a distinct preference for stony bottom habitats. Previous studies on Lake Hövsgöl have associated variation in macroinvertebrate communities with variation in substrate (Erbaeva et al., 2006) and studies on macroinvertebrate communities in oligotrophic lakes in New Zealand also showed that macroinvertebrate community structure was related to fine scale variation of substrate (Stoffels et al., 2005).

Oligochaete, bivalve, and Chironomid density did increase marginally in bays along the east shore of the lake relative to bays along the west shore (Fig. 4, Table 1). The lake's western shore slopes steeply into the lake where depth rapidly increases to the maximum depth of 260 m (Kozhova et al., 1989; Goulden et al., 2006). Lake slope can affect sediment accumulation (Blais \& Kalff, 1995) and thereby affect macroinvertebate community structure (Rieradevall et al., 1999; Stoffels et al., 2005), leading to differences in density between the two sides of the lake. Also, vertical nutrient spiraling can lead to a decrease in available nutrients. Hayford and Ferrington (2006) argued that the steep western slope of the lake produced a downward spiral of nutrients away from the littoral zone. Thus, fewer nutrients were available to support macroinvertebrates along the west side of the lake relative to the east side of the lake. However, numbers of the insectivorous, endangered arctic grayling were higher along the west shore (Ahrenstorff et al., 2012) indicating that dense enough benthic invertebrate communities were present to feed this consumer.

The implications of our research are important. Spatially heterogeneous macroinvertebrate communities will not respond in a homogeneous manner to a changing environment. Changes in land use along the east shore of the lake and climate change may cause increased flow of fine sediments into the lake's east shore bays. Temperatures have risen significantly in the Lake Hövsgöl region resulting in permafrost melt (Nandintsetseg et al., 2007; Sharkhuu et al., 2007). Permafrost melt into streams will increase the sediment load and concentration of dissolved organic carbon (Murdoch et al., 2000), compound- ing the effect of increased grazing (e.g. Puntsag et al., 2010) and increasing sediment loads flowing into Lake Hövsgöl. This, in turn, will affect community composition because of the degree of substrate preference shown by macroinvertebrates. In extreme cases increased sediment and nutrient loads may lead to increased densities of only a few taxa, such as chironomids (Hilsenhoff, 1988), leading to nuisance levels of emergence (sensu Ali, 1995). Conservation of Lake Hövsgöl should incorporate plans to monitor sediment load into the lake and the possible impairment of macroinvertebrates by changes in substrate and sedimentation so that the lake management can correct problems associated with land use change as they arise in order to conserve this pristine Blue Pearl of Mongolia.

\section{ACKNOWLEDGEMENTS}

This research was funded by the US National Science Foundation, Division of International Studies (INT \# 9504867). We are grateful for the assistance of Kristen McGill, Kevin Jurotich, and Sergio Orozco in sorting and enumerating the specimens. Special thanks go to the members of the 1997 expedition and the crew members of the Mongolian naval vessel the Sukhbaatar. Thank you to Mark Hammer and to three anonymous reviewers whose comments improved the manuscript. This research was conducted under the auspices of the Central Plains Center for Bioassessment.

\section{REFERENCES}

Ahrenstorff, T.D., O.P. Jensen, B.C. Weidel, B. Mendsaikhan and T.R. Hrabik. 2012. Abundance, spatial distribution, and diet of endangered Hovsgol grayling (Thymallus nigrescens). Environmental Biology of Fishes 94(2):465-476.

Ali, A. 1995. Nuisance, economic impact and possibilities for control. In: D. Armitage, P.S. Cranston \& L.C.V. Pinder (eds.), The Chironomidae: the Biology and Ecology of Non-biting Midges, Chapman \& Hall, London. pp. 339-364.

Barbour, M.T., J. Gerritsen, B.D. Snyder and J.B. Stribling. 1999. Rapid Bioassessment Protocols for Use in Streams and Wadeable Rivers: Periphyton, Benthic Macroinvertebrates and Fish. Second Edition. EPA 841-B-99-002. U.S. Environmental Protection Agency; Office of Water; Washington, D.C.

Belsky, A., J. Matzke and S. Uselman. 1999. Survey of livestock influences on stream and riparian ecosystems in the western United States. Journal of Soil and Water Conservation 54:419-431.

Blais, J. and J. Kalff. 1995. The influence of lake morphometry on sediment focusing. Limnology and Oceanogra- 
phy 40:582-588.

Cummins, K.S. and D.L. Graf. 2010. Mollusca: Bivalvia. In: J. Thorp and A. Covich (eds.), Ecology and Classification of North American Freshwater Invertebrates, Elsevier, London. pp. 309-384.

Erbaeva, E.A., O.M. Kozhova, O.M. and G.P. Safronov. 2006. The fauna of bottom invertebrates of Lake Hövsgöl. In: C. Goulden, T. Sitnikova, G. Gelhaus and B. Boldgiv (eds.), The Geology, Biodiversity, and Ecology of Lake Hövsgöl (Mongolia), Backhuys Publishers, Lieden, The Netherlands. pp. 259-278.

Goulden, C.E., O. Turmurtogoo, E. Karabanov and A. Mongontsetseg. 2006. The Geological History and Geography of Lake Hövsgöl. In: C. Goulden, T. Sitnikova, G. Gelhaus and B. Boldgiv (eds.), The Geology, Biodiversity, and Ecology of Lake Hövsgöl (Mongolia), Backhuys Publishers, Lieden, The Netherlands. pp. 1-19.

Govedich, F.R., B.A. Bain, W.E. Moser, S.R. Gelder, R.W. Davies and R.O. Brinkhurst. 2010. Annelida (Clitellata): Oligochaeta, Branchiobdellida, Hirudinida, and Acanthobdellida. In: J. Thorp and A. Covich (eds.), Ecology and Classification of North American Freshwater Invertebrate, Elsevier, London. pp. 385-436.

Hayakawa, K., T. Sekino, T. Yoshioka, M. Maruo and M. Kumagai. 2003. Dissolved organic carbon and flouresence in Lake Hövsgöl: factors reducing humic content of the lake water. Limnology 4:25-33.

Hayami, Y., M. Kumagai, M. Maruo, T. Sekino, S. Tsujimura and J. Urabe. 2006. Review of some physical processes in Lake Hövsgöl. In: C. Goulden, T. Sitnikova, G. Gelhaus and B. Boldgiv (eds.), The Geology, Biodiversity, and Ecology of Lake Hövsgöl (Mongolia), Backhuys Publishers, Lieden, The Netherlands. pp. 115-124.

Hayford, B. and L.C. Ferrington. Jr. 2006. Distribution of Chironomidae (Diptera) in Lake Hövsgöl, Mongolia. In: C. Goulden, T. Sitnikova, G. Gelhaus and B. Boldgiv (eds.), The Geology, Biodiversity, and Ecology of Lake Hövsgöl (Mongolia), Backhuys Publishers, Lieden, The Netherlands. pp. 433-452.

Hilsenhoff, W. 1988. Rapid field assessment of organic pollution with a family-level biotic index. Journal of the North American Benthological Society 7:65-68.

Kalbe, L. and D. Schacke. 1996. On the limnology of Lake Chowdsgol, northern Mongolia. Limnologica 26(3):293300 .

Kozhova, O.M., L.R. Izmest'eva and E.A. Erbaeva. 1994. A review of the hydrobiology of Lake Khubsugul (Mongolia). Hydrobiologia 291:11-19.

Kozhova, O.M., O. Shagdursuren, A. Dashdorj and N. Sodnom (eds.), 1989. Atlas of Lake Hövsgöl. Cartographic Ministry of USSR, Moscow, 118 pp (in Russian).

Mbaiwa, J. 2003. The socio-economic and environmental impacts of tourism development on the Okavango Delta, north-western Botswana. Journal of Arid Environments
54:447-467.

Mitamura, O., D. Khadbaatar and N. Ishida. 2010. Comparative investigation of chemical and biological characteristics in waters and trophic state of Mongolian lakes. Limnology 11:17-30.

Murdoch, P.S., J.S. Baron and T.L. Miller. 2000. Potential effects of climate change on surface-water quality in North America. Journal of the American Water Resources Association 36:347-366.

Nandintsetseg, B., J.S. Greene and C.E. Goulden. 2007. Trends in extreme daily precipitation and temperature near lake Hövsgöl, Mongolia. International Journal of Climatology 27:341-347.

Orkhonselenge, A. and K. Kashiwaya. 2010. Sedimentary feature on Borsog Bay, eastern shore of Lake Khuvsgul in Northern Mongolia. Annals of Warsaw University of Life Sciences-SGGW Land Reclamation 42:105-114.

Puntsag, T., J.S. Owen, M.J. Mitchell, C.E. Goulden and P.J. Mchale. 2010. Patterns in solute chemistry of six inlet streams to Lake Hövsgöl, Mongolia. Journal of Ecology and Field Biology 33(4):289-298.

Rieradevall, M., N. Bonada and N. Prat. 1999. Substrate and depth preferences of macroinvertebrates along a transect in a Pyrenean high mountain lake (Lake Redó, NE Spain). Limnetica 17:127-134.

Safronov, G.P. 2006. Gammaridae of Lake Hövsgöl. In: C. Goulden, T. Sitnikova, G. Gelhaus and B. Boldgiv (eds.), The Geology, Biodiversity, and Ecology of Lake Hövsgöl (Mongolia), Backhuys Publishers, Lieden, The Netherlands. pp. 201-216.

Sharkhuu, A., N. Sharkhuu, B. Etzelmüller, E.S.F. Heggem, F.E. Nelson, N.I. Shiklomanov, C.E. Goulden and J. Brown. 2007. Permafrost monitoring in the Hovsgol mountain region, Mongolia. Journal of Geophysical Research 112:F02S06.

Stoffels, R.J., K.R. Clarke and G.P. Closs. 2005. Spatial scale and benthic community organization in the littoral zones of large oligotrophic lakes: potential for cross-scale interactions. Freshwater Biology 50:1131-1145.

Urabe, J., T. Sekino, Y. Hayami, M. Maruo, S. Tsujimura, M. Kumagai, B. Boldgiv and C.E. Goulden. 2006. Some biological and chemical characteristics of Lake Hövsgöl. In: C. Goulden, T. Sitnikova, G. Gelhaus and B. Boldgiv (eds.), The Geology, Biodiversity, and Ecology of Lake Hövsgöl (Mongolia), Backhuys Publishers, Lieden, The Netherlands. pp. 387-402.

Vadeboncoeur, Y., P. McIntyre and M.J.V. Zanden. 2011. Borders of biodiversity: life at the edge of the world's large lakes. BioScience 61:526-537.

Yu, L. and M. Goulden. 2006. A comparative analysis of international tourists' satisfaction in Mongolia. Tourism Management 27:1331-1342.

Submitted: May 18, 2013, Accepted: August 12, 2013 